ACTA UNIVERSITATIS LODZIENSIS

FOLIA LITTERARIA POLONICA 8(38) 2016

http://dx.doi.org/10.18778/1505-9057.38.01

Dorota Samborska-Kukuć*

\title{
What a Suave Man he Was! [...] The Earth Trembled as he Perished. Two Polish Suicides: Wołodyjowski - Wokulski
}

To put the protagonist to death as a way of finishing the composition is a final dissolution of the plot and a form of analogy towards reality, that is a realism without illusions. It sometimes is the cruelty of the author, in other times an expression of boredom found in the created character or tiredness with the plot. The finals, not necessarily of a scale shocking the reader, are often combined with entelechy of the work, its internal force that is shaping it, they sometimes are a form of implication, they complement logical coherence carrying a message. The foreshadowings of the end of the protagonist inscribed in his fictional existence, even a kind of death, dictated in realistic texts by mimesis and probability, happen to be recognized and expected by the reader, or - if the author plays a game with them, encouraging a careful reading or multiple readings - hidden, encoded in the work ${ }^{1}$. There can be many ideas for putting the protagonist to death, however, often that strong final chord can have an interpretative value, which depends on the choice of a specific kind of death, or a kind of a commentary to the presented world: changes in its duration after the removal from it the actor or absolute decay².

A natural death, a murder, a suicide, or a tragic accident - those four main variants of death exhaust all the possibilities of choice although literature often reaches for variants of death which reside on the border, which are unclear, conjectural, stimulating with a concealment the activity of reflection and the reader's activity with apposition. The best known both metaphorical and literary deaths created by our nineteenth-century realists were the suicides of Michał Wołodyjowski and Stanisław Wokulski, repeating the spectacular deed of Ordon from Mickiewicz's

* Dr hab. prof. UŁ, The University of Lodz, Faculty of Philology, Institute of Polish Philology, Department of Positivism and Young Poland Literature; e-mail: ddsk@wp.pl.

${ }^{1}$ K. Bartoszyński, Problem lektury wielokrotnej, in: idem, Powieść w świecie literackości, IBL PAN, Warsaw 1991, pp. 165-185; U. Eco, Lector i fabula. Wspótdziałanie w interpretacji tekstów narracyjnych, transl. P. Salwa, PIW, Warsaw 1994, A. Martuszewska, "Kontynuacje” jako rzekome światy możliwe czytelnika, in: eadem, Światy (nie)możliwe powieści, Wydawnictwo UG, Gdańsk 2001, pp. 194-232.

${ }^{2}$ On endings of novels in the $2^{\text {nd }}$ half of the $19^{\text {th }}$ century. See A. Martuszewska, Poetyka polskiej powieści dojrzałego realizmu 1876-1895, Ossolineum, Wroclaw 1977, pp. 180-181. 
poem $^{3}$. They both died in the debris of the buildings which they had blown up - Wołodyjowski surrounded by the Turks in the fortress of Kamianets-Podilskyi, Wokulski demoted in his own humanity by aristocracy - in the debris of castle in Zasław. However, when Sienkiewicz put the protagonist to death, telling him (despite historical facts, after all real, stating that Wołodyjowski did not die in Kamianets-Podilskyi), to blow himself up in the powder-magazine of the fortress, Prus built him a sepulchre from understatements ${ }^{4}$. As finis mortem in Fire in the Steppe, the ending of a twelve-volume ${ }^{5}$ The Trilogy, being written continuously as a column for five years, it had the character of a final coda, resulting not only from teleology of the work, but from the fatigue of the creative effort taking five years ${ }^{6}$, it was the enigmatic, intriguing end of The Doll that grew in foreshadowing: the premonitions and suggestions of the protagonist. Are those literary suicides, inherent elements of romantic biographies, independent from each other, accidentally concurrent, or on the contrary, they are somewhat complementary or perhaps polemical? It is worth investigating this intriguing thread.

At the beginning of May 1888 Stowo, a Warsaw daily, published one of the last episodes of Fire in the Steppe, in which the protagonist committed suicide. Then, Prus was already printing The Doll in Kurier Codzienny.

${ }^{3}$ M. Piwińska viewed Wołodyjowski as a "new Ordon" sacrificing himself "as an example", Legenda romantyczna i szydercy, IBL PAN, Warsaw 1973, p. 30, this thread is developed by T. Bujnicki, Mały rycerz. O pojedynkach i samobójstwie Wołodyjowskiego, in: idem, Sześć szkiców o Zagłobie i inne studia sienkiewiczowskie, DiG, Warsaw 2014, p. 76.

${ }^{4}$ There were many works about the alleged death or rescue. One of the most interesting was an article by C. Kubaszewski, "Przecież to jasne, że Stach zabit się w Zasławiu...". Dynamika znaczeń w odbiorze "Lalki" Bolestawa Prusa (w aspekcie zakończenia powieści), in: Nowe stulecie trójcy powieściopisarzy, A. Makowiecki (ed.), Wydawnictwo UW, Warsaw 1992, pp. 183-195. See also J. Tomkowski, Prawdziwe zakończenie "Lalki", albo co się stało z Wokulskim, in: Bolesław Prus: pisarz nowoczesny, J.A. Malik (ed.), Wydawnictwo KUL, Lublin 2009, pp. 9-21.

${ }^{5}$ The quantity of the printed volumes in magazines and in the first edition were as follows: Fire and Sword, vol. 1-3, The Deluge, vol. 1-6; Fire in the Steppe, vol. 1-3. In Collected work (ed. J. Krzyżanowski) The Trilogy included thirteen volumes.

${ }^{6} \mathrm{H}$. Sienkiewicz in June 1887, or at the initial stage of Fire in the Steppe, wrote to Edward Lubowski: "By the way, I will say that I would like to finish the cycle and get to writing a modern novel that I do not know whether I need more health or this ending. [...] when something gnaws you or bothers you, you should take the contemporary world because when writing about such people as we are, it is easier to take something from what you have in your mind and heart, and the work does not seem to be so compulsory and it is more sincere", J. Krzyżanowski, Kalendarz życia i twórczości Henryka Sienkiewicza, in: H. Sienkiewicz, Works, vol. LVII, PIW, Warsaw 1954, pp. 200-201. All the quotations used in this article come from this edition.

Sienkiewicz wanted then to say goodbye to the world of The Trilogy and was thinking about a contemporary novel, "less compulsory and more genuine," so to speak. One should come to the conclusion that the writer was tired of the plot, what is more: he perceived such writing as not sincere and compulsory in a sense. In the context of this statement, Without Dogma would be a novel closer to the author, a form of autotherapy and an exposition of the problems of the contemporary world, so it would be closer to Prus. 
Exactly on 5 May 1888, in its $123^{\text {th }}$ issue Kurier printed the last episode of the first volume of the novel (book version: vol. 2, chapter IV entitled Surprises, Delusions and Observations of the Old Clerk). Not until the anniversary of the sealing of the destiny of Sienkiewicz's superhero, on 24 May 1889 (in the $142^{\text {th }}$ issue of Kurier) was the episode published, in which Prus suggested Wokulski's suicide in the castle ruins. The fact that Prus knew The Trilogy, is without any doubt; he was interested in the works by Sienkiewicz, he carefully read With Fire and Sword reviewing it, quite aptly in fact, in Kraj, where he praised the author for the general specification of the characters ("He paints people with distinct, numerous and fixed features, i.e. in such a way as we see them in life. He can be considered as a role model for other authors"7) but he reprimanded him for creating myths and for uselessness (his characters "make an impression", but do not teach and do not explain anything. Meanwhile even in the previous novels of Sienkiewicz we find a new type of gimnasium student, an immigrant, a writer Zołzikiewicz and other similar, which shed some light on the "social relations" ), and reprimended for falsifying the history ("the author is unceremonious about history and all the time on the wings of fantasy detaches from the ground"9). It is impossible not to notice polemical accents towards With Fire and Sword in The Outpost ${ }^{10}$. In general, the romantic commitments of Sienkiewicz as a lover of a resounded Mohort (fantasy, idealisation of the future, apotheosis of the nobility, romantic poses, justifying everything with the faith in God's protection, etc. $\left.{ }^{11}\right)$ and creators of historical novels are for Prus the scientist, who stubbornly wrote (before Pharaoh) only contemporary novels, unacceptable - even because of the so visible reason as the change of the quantifier: from "national" to "social", which was, at least to some extent, influenced by the Pan-Slavism of Prus. In the primary meaning national affiliation was pushed out by social status and the fate of individuals and various groups depended on it. Thus, the use of national categories which shape the sense of unity of all the Poles and at the same time the collective responsibility resulting from a common doctrine of patriotism is deceptive. How this matter was in the past, it was set forth clearly enough by Maria Konopnicka in a well-known, still valid poem And when the king went to war.

The final fate of the "Little Knight" could have served to Prus as an inspiration to the discussion on existential and social issues or polemics concentrating on

${ }^{7}$ B. Prus, "Ogniem i mieczem”. Powieść z dawnych lat Henryka Sienkiewicza, in: idem, Pisma, vol. XXIX, Studia literackie, artystyczne i polemiki, Z. Szweykowski (ed.), PIW, Warsaw 1950, p. 38

${ }^{8}$ Ibidem, p. 45.

${ }^{9}$ Ibidem, p. 54.

${ }^{10}$ J. Bachórz, "Lalka" w kontekście "Trylogii", "Rocznik Towarzystwa Literackiego imienia Adama Mickiewicza", Yearbook 26/27: 1991/1992, pp. 28-31.

${ }^{11}$ Connections of Sienkiewicz with romanticism have been analysed by S. Meresiński, Henryk Sienkiewicz wobec tradycji romantycznej, Wydawnictwo Pedagogiczne, Kielce 1992. 
"great questions of the epoch", not the past, which one does not derive the truth from because there are not any legends and myths leaning out towards utilitarian fiction. The polemic nature, apart from a peculiar kind of Wokulski's death evoking his blowing out, also indicates that the suicidal considerations of Wokulski, more or less distinct, appeared on the pages of The Doll not until volume II, that is in fragments being written after the reading of Fire in the Steppe. Józef Bachórz, whose valuable considerations are crucial for this article, wrote:

one should think about the bitterness emanating from the last pages of The Doll, taking into account the heartening endings of consecutive pats of The Trilogy. In May 1888, Sienkiewicz ended the heroic story of Michał Wołodyjowski with an explosion in the fortress in Kamianets-Podilskyi. A year later [...] as an echo of that explosion a detonation in the debris of castle in Zasław is heard.

How typical are the differences in the symbolic meaning of those final explosions in both novel castles.

In the debris in Kamianets-Podilskyidied sacrificing himself a knight of the ramparts of Christianity, in order to - having fulfilled the service to God and his homeland - depart to accept his eternal award. That death, although sir Michael's close relatives will mourn it with tears, was not a tragedy but a victory. [...]

Zasław rockfalls covered - if one accepts the version stubbornly repeated in The Doll by doctor Szuman - Wokulski the suicide: a desperate, distraught and a psychologically unbalanced man who after the failure of his dreams could not find hope. Szuman's hypothesis about Wokulski's being crushed by the "remains of the feudalism" brought no consolation, neither did any other hypothesis. The mysterious disappearance of Wokulski - possibly his death in the Zasław ruble - and Ignacy Rzecki's death create a moving invitation for the reader to reflect for a moment. To reflect on the existential troubles and the dangerous social phenomena of the present day. An invitation to reflect and to take responsibility for the present day and tomorrow. Because Prus put the value of that reflection above consoling promises ${ }^{12}$.

A protagonist of a historical novel and a protagonist of a contemporary one. A knight destined to war, and a merchant "born to be a civilian"13. Short Wołodyjowski and strapping Wokulski. Both of them forty-six years old, mature. Both without mothers, but with fathers: Wołodyjowski Sr., patronizing his son about the necessity of gaining abilities which command respect and fear ("God gave you a meagre figure, if people are not afraid of you - they will laugh at you"14), old Wokulski, who wanted to ensure a noble stature for his son ("Why

\footnotetext{
${ }^{12}$ J. Bachórz, "Lalka" w kontekście "Trylogii”..., pp. 38-39.

${ }^{13}$ Ibidem, p. 34.

${ }^{14}$ H. Sienkiewicz, Potop, vol. 2, p. 56.
} 
spend money on books?... Give it to me because if I have to stop the trial, everything will be wasted" ${ }^{15}$ ). Wołodyjowski obediently followed those guidelines, meanwhile Wokulski, not caring (at that time) about titles, treated them as outdated. Both had their mentors: Wołodyjowski - Zagłoba ${ }^{16}$, who often brought his dilemmas to the firm ground of realism, dispelled sorrows, and finally he marries him with the chosen woman; Wokulski had Rzecki, who although seemingly appeared to be out of touch with reality and involved with the past, and he was not an effective matchmaker, he proved himself in important moments with surprising perspicacity, even prophecy:

Wierz mi, Stachu, ja nie jestem tak naiwny, jak myślą. Wiele w życiu widziałem i doszedłem do wniosku, że my - wkładamy zbyt dużo serca w zabawę nazywaną miłością! Ażeby nad kobietami odnosić wielkie zwycięstwa, trzeba być w miarę impertynentem i w miarę bezczelnym: dwie zalety, których ty nie posiadasz. I dlatego ostrzegam cię: niedużo ryzykuj, bo zostaniesz zdystansowany, jeżeli już nie zostałeś. Nigdym do ciebie o tych rzeczach nie mówił, prawda? nawet nie wyglądam na podobną filozofię... Ale czuję, że grozi ci niebezpieczeństwo, więc powtarzam: strzeż się! i w podłej zabawie nie angażuj serca, bo ci je w asystencji lada chłystka oplują. A w tym wypadku, mówię ci, człowiek doznaje tak przykrych wrażeń, że... Bodajbyś ich lepiej nie... doczekał!... ${ }^{17}$

[Believe me Stach, I am not as naive as some people think. I have seen a great deal in my life, and I have come to the conclusion that we put too much heart into the game called love! To gain a great victory over a woman one must be both ruthless and shameless: two virtues you haven't got. That is why I am warning you: do not risk too much, for you will be outdistanced, if you haven't been already. I have never spoken to you of such thing before, have I? I don't even look like a philosopher. ... But I feel you are threatened by danger, so I repeat: be aware! Do not engage your heart in a shameful game, for with her at your side you will be derided by any Tom, Dick and Harry. And I must tell you that when that happens a man feels such bitterness that... better not live to see it! $]^{18}$

As Wołodyjowski as Wokulski had no luck in love, placing their feelings in unsuitable women but Wołodyjowski, whose love zeals to different women and ladies were shallow and boyish, destiny (not without Zagłoba's help) sent at least

${ }^{15}$ B. Prus, Lalka, vol. II, J. Bachórz (ed.), Ossolineum, Wroclaw 1998, p. 27, the cited quotations from The Doll come from this edition.

${ }^{16}$ T. Bujnicki wrote about it, op. cit., pp. 79-80.

${ }^{17} \mathrm{~L}, \mathrm{I}, 580$.

${ }^{18}$ B. Prus, The Doll, transl. from the Polish by D. Welsh. All the English quotations used in this article come from this translation. 
Basia, "a hayduk", for whom the "Little Knight" was an ideal man and human", despite visible deficiencies in terms of beauty ${ }^{20}$. Wołodyjowski, slowly reacting to advice and recommendations, supported his - fairly mediocre reason - on others astuteness. The stubborn and impulsive Wokulski ignored everybody and listened to no one. Blinded by the romantic myth of womanhood, disgusted with his how dissimilar from the romantic ideal marriage, he fell in love with an aristocrat who despised him, not seeing the chance given by fate in the person of Helena Stawska. Just like Epimetheus, Wokulski chose miss Izabela as the woman of his life, who came from a class falling into oblivion, who instead of returning his feelings and respect the dedication of the man in love with her, opened the Pandora's box releasing all troubles and sorrows imaginable. It is worth adding that those two types of women: Baśka and Izabela were at the same time the reasons of the happiness and misery of the men who loved them, which resulted directly from their systems of values: Wołodyjowski defeated Azja and Wokulski was defeated by Starski, because that was what the women decided.

Both characters chose similar ways of self-annihilation: they blew themselves up. However, the circumstances of making the decision about suicide were completely different. Wołodyjowski did not die alone, he was accompanied by Ketling, who shared with him a "terrible" oath ${ }^{21}$. Wokulski is and he wants to be alone (without God as well), kills himself because he feels that his life has expired:

nareszcie zrozumiał, że jest zapomniany i nikomu niepotrzebny. Był podobny do rzuconego w wodę kamienia, nad którym w pierwszej chwili powstaje wir i zamęt, a później tylko rozbiegają się fale coraz mniejsze, coraz mniejsze... I w końcu nad miejscem, gdzie upadł, tworzy się gładkie zwierciadło wody, gdzie znowu przebiegają fale, lecz zrodzone już w innych punktach, wywołane przez kogo innego ${ }^{22}$.

[He realised that he himself was forgotten and superfluous. He was like a stone dropped into the water, at first causing a whirlpool and movement, but later on smaller and smaller waves flow away. Finally, above the place where he had fallen, a smooth mirror of water was recreated, where waves flowed again, but now originating from other places, caused by other people.]

${ }^{19}$ See G. Matusiak, Państwo Wołodyjowscy jako malżeństwo nie tylko barokowe, "Acta Universitatis Lodziensis. Folia Litteraria Polonica" vol. 7 (2005), issue 1, pp. 279-302.

${ }^{20}$ It is interesting that a threat of the short height of Wołodyjowski was no longer talked about from his wedding with Basia, as J. Krzyżanowski pointed out, "Trylogia" - powieść ludowa, in: idem, Pokłosie Sienkiewiczowskie, PIW, Warsaw 1973, p. 228.

${ }^{21}$ B. Mazan emphasized the fatalism and determinism of the Wołodyjowski and Ketling's oath in: Wstęp in: H. Sienkiewicz, Pan Wołodyjowski, B. Mazan \& D. Mazanowa (eds.), Ossolineum, Wroclaw 1995, p. 42.

${ }^{22}$ L, II, 600 . 
The space of deed is also meaningful. On the one hand, the fortress in Kamianets-Podilsky is a place chosen by history for "the ramparts of Christianity", and which Sienkiewicz gave a special virtue of gloria victis, ruins in Zasław are, on the other, an exceptional territory. It itself is exceptional because it is a remnant of the past splendour, also for Wokulski, because it is a magical place from his childhood, where he used to go with his uncle in order to listen to the stories about his unfulfilled love; it is where he confessed his love to Izabela, stunned with the legend of that place, which was told to them by Wegiełek, a local blacksmith. The condition of Wokulski's emotions was an equivalent of that wonderful castle - a ruin ("Can't you see that I have already been only ruin, the worst because moral..." ${ }^{23}$ ) - he confessed to Rzecki. The protagonist imitated the space characterised by special virtues and there he looks for finality - a death in the well in Zasław, absolute annihilation, the perfect suicide. Węgiełek's mother heard two explosions ("w zamku dwa razy tak strasznie huknęło, jak pioruny, a w miasteczku szyby się zatrzęsły" / "there were two terrible bangs in the Castle, like thunder, and the window panes rattled all over the village" 24 ): in the first explosion Wokulski blew out a stone with a deceitful poem of Mickiewicz; he took the other stick of dynamite to the well:

Kamień, cośmy, na nim rok temu wycięli wiersze - pisze w liście Węgiełek - rozbity na jakie dwadzieścia kawałków, a w tym miejscu, gdzie była zawalona studnia, zrobił się dół i gruzów nasypało w niego więcej niż na stodołę 25

[The stone we wrote verses on last year was broken into at least twenty pieces, and on the spot, where the fallen-in well had been, there was a hole, and the rubble had piled up as high as a barn over it]

They both died childless being the last in their families ${ }^{26}$. Then the only thing that let them survive was memory of posterity, which Wołodyjowski cared about, and which Wokulski did not want. Wołodyjowski had a beautiful, knight's funeral, typical of the $17^{\text {th }}$ century pompa funebris in the Stanislavian collegiate church with a moving sermon by father Kamiński and a farewell - "a convulsive Basia's shout" ${ }^{27}$; Wokulski, sent off by nobody, received a modest obituary - a quotation

${ }^{23}$ L, II, 580 .

${ }^{24} \mathrm{~L}, \mathrm{II}, 685$.

${ }^{25}$ Ibidem.

${ }^{26}$ It is an interesting thread in the decadent mind; Sienkiewicz developed it - obviously - in Without Dogma in a character of Leon Płoszowski.

${ }^{27}$ On the atmosphere of Wołodyjowski's funeral see L. Ludorowski, Requiem finalne "Pana Wołodyjowskiego", in: idem, Wizjoner przeszłości. Powieści historyczne Henryka Sienkiewicza, Wydawnictwo UMCS, Lublin 1999, pp. 334-342. 
from Horace: Non omnis moriar, which the parish priest from Zasław (just in case) ordered to be placed in the ruins, and which replaced the engraving on the stone with Mickiewicz verse turned to ash. That adapter for an epitaph line from Horace will fulfil the function of an obituary, which the Duchess Zasławska will foresee anticipatingly saying:

Pod zamkiem więcej bywa ludzi niż na cmentarzu, prędzej przeczytają i może zamyślą się nad ostatecznym kresem wszystkiego na tym świecie, nawet miłości... ${ }^{28}$.

[More people visit the castle then the cemetery, they will read it, and perhaps think of the final limits of everything in this world, even love]

The fame of the knight, which the protagonist created by Sienkiewicz gained posthumously was a result of his patriotic determination, oath; motivated by his love for his homeland and the myth of his own invincibility, in a situation of besetment he had to deprive himself of life in order to avoid the humiliation of being captured, of surrendering the fortress. Thus, he sacrificed his beloved wife, bidding her farewell with the well-known: "That's nothing!" preceded by a litotic, farcical, even ludic lecture about post-mortem meeting, hard-bitten with the rhetoric of passage 21 of the Revelation. Sienkiewicz wrings readers' tears, ordering to be witnesses to the knight's attitude, for whom God, honour and homeland are a strict and inviolable credo of life, which he sealed with his own death ${ }^{29}$. That death circled around "a small falcon" - in recollections, reflections, even visions from the very beginning of that part of The Trilogy $y^{30}$. For Wokulski patriotism in a war dimension is finished by a gloomy assertion in the words "I was deceived", which he uttered having returned from Siberia, he was embittered not only of the global results of that rebellion, but also the personal disappointment, because his compatriots instead of appreciating his devotion, resignation from academic and personal plans for fulfilling the patriotic duty removed him to the dregs of the society and they gossiped about him mercilessly. "Having broken himself in heroism" he cannot become a "humble worker" because the innate pride and belief in myths prevent him from that. Homeless and disillusioned, he found a narrowminded haven in the arms of an aged widow of Mincel, a German shopkeeper. Although he had something to live off, he confessed to Rzecki:

\footnotetext{
${ }^{28}$ L, II, 291.

${ }^{29}$ On the mythicality (fabulousness) of Wołodyjowski see: W. Krzemińska, Bohater mityczny w powieściach polskich i francuskich, PWN, Warsaw 1985, pp. 19-20, 50.

${ }^{30}$ L. Ludorowski pointed it out in: "Pan Wołodyjowski". Ostatnia część "Trylogii", in: idem, Wizjoner przeszłości..., p. 176.
} 
Ten spokojny chleb [...] dławił mnie i dusił przez lat sześć! ${ }^{31}$

[That good living [...] was stifling me and stifled me for six years]

Wokulski is a type of man who must have a noble goal in his life, and since gathering fortune is not a goal for him, he made it into a tool to access the aristocratic realm. That proved to be much more dangerous than the dangers of the battlefield, both fighting as a partisan and during a war in Bulgaria:

pomiędzy kulą, nożem i tyfusem ${ }^{32}$.

[amidst bullets, knives and typhus]

Dangerous as Wokulski full of myths and illusions did not have the strength to follow the sensible advice of Miss Meliton and make his conditions. The apparent luxury and the superficial beauty dazzled him and Wokulski lost man's innate sense of reality. The defeat of the protagonist had a decentralising character, caused by deformed expectations, with which the idealistic nature of Wokulski will be fertilized by reading in a literal and uncritical way poems by Mickiewicz (who, paradoxically, was able to draw happiness from love, not exactly spiritual):

Bo któż to miłość przedstawiał mi jako świętą tajemnicę? Kto nauczył mnie gardzić codziennymi kobietami, a szukać niepochwytnego ideału?... Miłość jest radością świata, słońcem życia, wesołą melodią w pustyni, a ty co z niej zrobiłeś?... Żałobny ołtarz, przed którym śpiewają się egzekwie nad zdeptanym sercem ludzkim! ${ }^{33}$

[Who taught me to despise ordinary women, and seek an unattainable ideal?... Love is the joy of the world, the sun of life, a cheerful melody in the wilderness, but what did you make of it?... A mournful altar, in front of which obsequies are sung over trampled human hearts!]

A man of robust energy, who could even lift national leadership, as Piotr Chmielowski assumed rightly reviewing The Doll ${ }^{34}$, ended in the ruins in Zasław - effectively and according to his intention. The Polish present and the Polish past lessened and eventually destroyed that power, wrestling with Wokulski with the strength of heart and soul. Romantic myths about Grażynas, Aldonas and Marylas, which he had "nurtured" for years resulted in miasmas, forgeries, literar inventions.

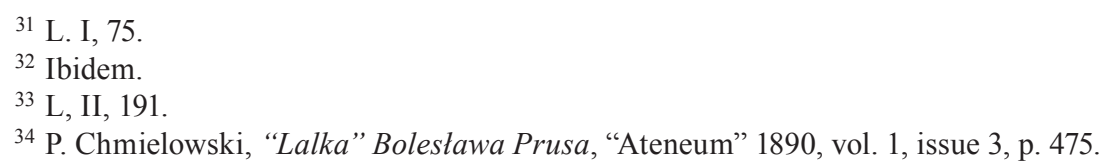


Equipped with such ideals the protagonist naively thought that he had met that embodiment of perfection. But she appeared to be a brutal reverse of his dreams and visions. Such a discovery, which had been increasing for a long time, is a repeated and the final collapse of his world, another painful statement: "I was deceived". A thorough conversion of the axiological principles of an adult man is rather impossible and the suicide, as a manifestation of not as much anger towards the reality as regret about oneself, shame of self-alienation and exhaustion of vital forces.

Wołodyjowski's fate who finally found his family happiness and enjoyed respect as a knight, have a coherent educationally correct crowning. He died a heroic death, and he did it at the right time, so he becomes hero and a legend. One must remember, though, Prus's comments, which he made in that matter towards Skrzetuski: "his knight's heart is only a drawer for public affairs, not an organ of personal feelings" ${ }^{\prime 3}$, being surprised at the life improbability of events, in which the protagonist had been involved, acting "for the public good". And Prus formulated the charge towards Sienkiewicz fairly vividly as "dipping the brush in the bucket of sacrifice" 36 . If it comes to Wołodyjowski, Sienkiewicz became additionally embroiled in an ethical problem connected with the conscious decision of suicide ${ }^{37}$, because this deed, denying life as a gift and an imperative to act, it is an offence against the most important Christian principle. And Sienkiewicz did show Wołodyjowski as a Catholic ${ }^{38}$. However, as Tadeusz Bujnicki claimed - in the novel "the dictate of knightly and patriotic fidelity prevails over the religious axiom" ${ }^{39}$ in the novel, especially that the protagonist's "suicidal acts is motivated above the individual" ${ }^{\prime 4}$. Probably it was, as far as the protagonist's suicide remains in the sphere of history, as a tale of a $17^{\text {th }}$ century's knight, but as a paradigm of behaviour for Sienkiewicz's contemporaries - surely was not ${ }^{41}$.

Wokulski, having been saved from the war storms, persisted in no-time, unsuccessfully searching his place and occupation destined for him, and finally finding it - as he thought - the goal of his life, will pay through the nose for that mistake. Forty or so years old man who cannot objectively judge the situation, wallowing in suffering and continuous uncertainty, which instead of harmony

\footnotetext{
${ }^{35}$ B. Prus, Ogniem i mieczem..., p. 42.

${ }^{36}$ Ibidem.

${ }^{37}$ As far as for Petronius the Roman taking his own life was a deed written into his world view and mentality, for the decadent Płoszowski, as well as the bankrupts: Kromicki or Maszka, it was a tragic end of life complications, suicide of Wołodyjowski contradicted with his faith.

${ }^{38}$ B. Mazan, Impresjonizm "Trylogii” Henryka Sienkiewicza, Wydawnictwo UŁ, Łódź 1993, p. 170.

${ }^{39}$ L. Ludorowski, Requiem finalne..., pp. 81-82.

${ }^{40}$ Ibidem, p. 82.

${ }^{41}$ As an example can be Emilia Chwastowska, who after Litka's death, won't dare to suicide, deciding on joining Daughters of Charity and burdening with to omany tasks, speeding up her natural death.
} 
with the world and people caused chaos and did not stop at such a nonsense, must have a problem with his identity. Wokulski - man of "transitional times", somewhat the generation of the 1863 uprising, as well as a generation of science enthusiasts and followers of work as a sign of patriotism, raised on romantic poetry, stranded early on, a bit of a romantic and a bit of a realist - typical representative of the social "middle" looking for a home, which he cannot find. It is a private, personal defeat of the protagonist who left nothing - as the old clerk said: "He wanted to do so much, he could had done so much yet he did nothing" ${ }^{\prime 2}$. But that is what man is like. All he wants is to be happy:

Nie jestem Chrystusem, ażeby poświęcać się za całą ludzkość [...] Zrobię, co się da i komu można, lecz osobistego szczęścia nie wyrzeknę się, to darmo... ${ }^{43}$

[I am not Christ, to sacrifice myself for mankind [...] I will do what can be done, but I won't renounce my own happiness, that's too much.]

- Wokulski thought. Privacy and at the same time apolitical nature of the protagonist is visible mainly in his conversation with Rzecki, who in his Napoleonic fantasy imagined Wokulski as at least the Turkish Wallenrod:

Myślałem, że człowiek, który naraża się na śmierć i... na plotki dla zdobycia majątku, ma jakieś ogólniejsze cele...

- A dajcież mi raz spokój z tym waszym ogółem!... - wykrzyknął Wokulski, uderzając pięścią w stół. - Co ja robiłem dla niego, o tym wiem, ale... cóż on zrobił dla mnie!... Więc nigdy nie skończą się wymagania ofiar, które mi nie dały żadnych praw?... Chcę nareszcie raz coś zrobić dla samego siebie... Uszami wylewają mi się frazesy, których nikt nie wypełnia... Własne szczęście - to dziś mój obowiązek... Inaczej... w łeb bym sobie palnął, gdybym już nic nie widział dla siebie oprócz jakichś fantastycznych ciężarów. Tysiące próżnują, a jeden względem nich ma obowiązki!... Czy słyszano coś potworniejszego?...44

[I thought that a man who had risked death and... And gossip to acquire a fortune would have something higher aim...

- Don't mention higher aims to me - Wokulski cried, banging the table - I know what I have done for those higher aims, but what have they done for me!... I want for the first time to do something for myself!... My head is full to overflowing with clichés that no one ever puts into action!... Personal happiness - that's my obligation now...

\footnotetext{
${ }^{42} \mathrm{~L}, \mathrm{II}, 667$.

${ }^{43} \mathrm{~L}, \mathrm{I}, 182$.

${ }^{44} \mathrm{~L}, \mathrm{I}, 578-579$.
} 
Otherwise I had shoot myself, if I didn't see something for myself Ahead, other than monstrous burdens. Thousands of people are idle, but one man has his duty towards them!... Did you ever hear anything more abominable?]

Wołodyjowski and Wokulski are "living fictions" - protagonists strengthening in the memory of the reader - a defined reader, looking for personal patterns based on simple, clear principles and denying the existing of a hero at all. A high-value, morally unambiguous Polish knight, serving the idealistic triad of Polish patriotism and a lost in post-uprising reality ex-insurgent, ex-naturalist, finally ex-merchant, unsuccessfully courting an impoverished noblewoman. Wołodyjowski through beautiful and brave deeds built his own monument, which will give him a posthumous fame and undisputed admiration of the readers. Wokulski lost everything that he owned, and that he gained with difficulty, against common sense he wasted his talent, money, energy - astounding the reader who is becoming more and more disappointed with his attitude. The homogeneity and coherence of Sienkiewicz's solutions demand to see in Wołodyjowski hero-legend, shaped deliberately as an educational example, in which national myths built on pathos are being fulfilled. Wokulski, because of his duality ("there are two men in me, he thought, one quite sensible, the other a lunatic" / "we mnie jest dwu ludzi, jeden zupełnie rozsądny, drugi wariat"45, "two men are merged in him: a Romantic of the pre-1863 kind, and a positivist of the 70s. What onlookers find contradictory is perfectly consistent with Wokulski himself" / "stopiło się w nim dwu ludzi: romantyk sprzed roku sześćdziesiątego i pozytywista z siedemdziesiątego. To, co dla patrzących jest sprzeczne, w nim samym jest najzupełniej konsekwentne"46) is a complicated creation, what is more - his fate is a parody of mythical biographies.

Michał Wołodyjowski was a figure which Sienkiewicz needed, among others, to fulfil the compensating myth. The writer, taking into account the fact that historic space-time associates with the forthcoming fall of the Republic of Poland, he concentrated all the patriotic expression on the "knight's spirit", on the strength lying in an inviolable ethos ${ }^{47}$. Thus, his protagonist, although rather sickly and not especially intelligent, when challenging an enemy he became a giant, an invincible hero - he gained such mastery in fencing. With his suicide death, which he preferred to surrendering to the enemy, he proves his character, unconditional devotion to public affairs and honour; he left almost a mythical fame of a knight and... a widowed wife. In the final analysis, even despite the tragic ending and a detachment from reality (sending Wołodyjowski by Potocki to a lost post, announcing early surrender), the character of Sir Michał in his invincibility is to send an optimistic message, and,

${ }^{45} \mathrm{~L}, \mathrm{I}, 464$.

${ }^{46} \mathrm{~L}, \mathrm{I}, 322$.

${ }^{47}$ Z. Szweykowski, "Trylogia” Sienkiewicza i inne szkice o twórczości pisarza, Wydawnictwo Poznańskie, Poznań 1973, pp. 33-34. 
at the same time, is to constitute a parenetic model of chivalric ethos, subjected to practical transgressions resulting from the need of the times.

Wokulski is the epitome of Prus's pessimism understood as irony ${ }^{48}$ and repeated in many novels, from Souls in Bondage to Pharaoh. Escaping on his own from Hopfer's cellar, foreboded a spectacular evolution, a symbolic way up. Though the beginnings of this way are indeed impressive, as Wokulski is involved in patriotic affairs, he achieved scientific success, even commercial, an enchantment with a woman and efforts to conquer her are not only deplorable in their absurdity, but lead the protagonist to the defeat. Passion becomes for him a destructive power. When the moment of enlightening came, when "ideal hits the ground", Wokulski tried to save his reputation by committing suicide. Saved by a miracle, he repeated the act of suicide and probably blew himself up in Zasław. That is man of "transgression times", our times - the author said - a naturalist to be, who interrupted his education to join the uprising and understand that he had deceived politically, a widower of wealthy merchant's wife and an owner of a well prospering shop, who had fallen in love like a schoolboy in an aristocrat, at whose feet he placed all his hopes and dreams. Poisoned with the fumes of romanticism, he did not want to and he could not get rid of his illusions.

In the late-1 $19^{\text {th }}$ century, it was not the Turks who besieged the Poles - the author of The Doll seemed to point out. The enemy is a remaining rudiment of feudalism and an unjustified sense of superiority of the idle class of different counts and barons with tiles bought abroad, who ask for everything while offering nothing. Despite the fact that their time was over, that they were in the very sense of the word "morituri", they usurped the right to self-determination. Thus, - against common sense, against progressive changes - such a right was given to them by the one, who holding all the trump cards, that is money, easily could force them to obedience and submission, thus showing their true colours, real values and pointing them to their place. As Szuman said:

Ludzie twojej energii rozkazują - nie słuchają, prowadzą - nie zaś są prowadzeni... ${ }^{49}$

[Men of your energy give orders, they do not take them, they lead, they are not led...]

Meanwhile, petrified habits and false imaginations of Wokulski led to a paradox: man of the future (and a merchant!) surrendered his treasures to past ghosts. Such an investment had to be unsuccessful. Wokulski was a victim of romantic illusions and sentimental belief in eternal love, covering sometimes feelings with

\footnotetext{
${ }^{48}$ See A. Martuszewska, Bolestawa Prusa "prawidla" sztuki literackiej, Wydawnictwo UG, Gdańsk 2003, pp. 120-121.

${ }^{49}$ L, II, 586.
} 
the mask of cynicism, when he spoke about natural selection and nature's monism. He did not wake up from the illusion until scoffed and pitied, when first the despair of disappointment and then the disgust towards himself gave birth to a dream of absolute death, desire, which - against his will, driven by the apogee of the disgust to his own delusion - he confessed to Szuman:

Chciałbym zapaść się pod ziemię, choć tak głęboko jak... studnia w zasławskim zamku... I jeszcze chciałbym, ażeby mnie zasypały gruzy, mnie i mój majątek, i nawet ślad tego, że kiedykolwiek istniałem. Oto moje pragnienia, owoc wszystkich poprzednich $^{50}$.

[I should like to sleep under the earth, as deep as the well in the Zasław castle... And also I'd like them to heap me with ruins, and me and my fortune, and even any trace of the fact that I ever existed. These are my desires, the fruit of all the ones that went before]

If confronted with Wołodyjowski Wokulski seems more genuine and credible ("more honest and non-forcibly"), appeals to the reader at the end of the $19^{\text {th }}$ century with a probability of biography, as a sort of catharsis - a kind of warning, not an unattainable model locked in the past. The reader knows that The Republic of Poland did not exist for 100 years and it is not a bulwark of Christianity anymore; there are not any Kamianets-Podilskyifortresses besieged by Turks, from who in fear (and disgust) one should look for escape in a spectacular death. Polish reality is completely different but by no means less demanding:

Romantycy muszą wyginąć - wieszczy Szuman - to darmo; dzisiejszy świat nie dla nich... Powszechna jawność sprawia to, że już nie wierzymy ani w anielskość kobiet, ani w możliwość ideałów. Kto tego nie rozumie, musi zginąć albo dobrowolnie sam ustąpić... ${ }^{51}$

[Romantics must die out, that's clear - Szuman prophesies-Today's world isn't for them... Common sense means we don't believe either in the angelic nature of women, nor in the possibility of ideals. Anyone who doesn't see this, must perish or give way of his own accord]

The burden of romantic ideals, legends of invincible warriors, hypnotising with patriotic spells and adoration for the native depression and martyrdom is clearly an element of Polish identity, which more than once will surface in our history in situations of threat.

\footnotetext{
${ }^{50} \mathrm{~L}, \mathrm{II}, 557$.

${ }^{51} \mathrm{~L}, \mathrm{II}, 687$.
} 
It is typical of The Doll that Wokulski becomes aware of the Polish myths and complications when staying abroad and when mixing with foreigners. In Siberia, he was fulfilled as a naturalist, gaining scholarly recognition. In Paris, he discovered that love can be a joy, not suffering. Suzin, a Russian merchant, taught him about commerce devoid of naive sentiments, clearly revealing Polish embroilment in emotions:

Ot, co was gubi wszystkich Polaków, u was na wszystko: i na handel, i na politykę, i na kobiety, u was na wszystko - serce i serce... I to jest wasze głupstwo. Na wszystko ty miej kieszeń, a serce tylko dla siebie, ażeby radować się z tego, co kupisz za pieniądze ${ }^{52}$.

[Here is what causes your downfall, all you Poles: with you it's heart, all heart, for everything, for trade, politics, women, everything and that is yours. Have a pocket for everything, but keep your heart only for yourself in order to enjoy what your money buys].

It is an admonition, which remained unchangeably universal. Wokulski realized:

Wszystko, co umiem, wszystko, co mam, wszystko, co zrobić jeszcze mogę; nie pochodzi stąd. Tu znajdowałem tylko upokorzenie, zawiść albo wątpliwej wartości poklask, gdy mi się wiodło; lecz gdyby mi się nie powiodło, zdeptałyby mnie te same nogi, które dziś się kłaniają...

[Everything I know, everything I have, everything I can still achieve, does not come from here. Here I have found only humiliation, envy or applause of dubious value when I was successful: if I had been not successful, whose who bow to me today...]

and then:

Kiedy z własnej literatury wyniósł złudzenia, które zakończyły się rozkładem jego duszy - ukojenie i spokój znajdował tylko w literaturach obcych. Czy my naprawdę - myślał z trwogą - jesteśmy narodem marzycieli i czy już nigdy nie zejdzie anioł, który by poruszył betsedejską sadzawkę obłożoną tylu chorymi? ${ }^{53}$

[Whereas he had drawn the illusions which had terminated in the dissolution of his own soul from Polish literature, he found solace and peace only in foreign literatures. Are we really a nation of dreamers? - he wondered in alarm, - and will the angel who touched the pool at Bethesda, surrounded by sick people, never descend upon us?]

\footnotetext{
${ }^{52} \mathrm{~L}, \mathrm{II}, 700$.

${ }^{53}$ L, II, 564.
} 
Prus offered a bitter and sad accusation of Polish myths, fundamental for native mentality.

Another aspect seems to bring closer both novels: decay, hasty liquidation of the presented world and a suggestion of a continuation. In the Epilogue Sienkiewicz informed about death of the supporting characters (Nowowiejski, Muszalski, Motowidło) while the fates of the protagonists (Zagłoba, Wołodyjowska, Ketlingowa) are ignored; what did mention, however, was the bravery of the six brothers Skrzetuski as a form of vitality of the Polish national spirit ${ }^{54}$. The Doll ends very pessimistically, after Wokulski's disappearance the world starts to fall apart, along with Rzecki's death the narration fades away. Ochocki plans his trip, but ,people won't be lacked"55, and both Szlangbaum and Maruszewicz will stay in Warsaw, as well as small upstarts watching the world, through the glass of bottles". It would be a misunderstanding to consider the end of The Doll as an expressis verbis polemic with the "consolation" of The Trilogy, as Józef Bachórz pointed out adding:

nie należy sobie przysłaniać oczu na to, że Prus kończył swoje dzieło wiosną 1889 r., czyli w atmosferze powszechnego aplauzu dla krzepicielskich zalet Trylogii i w atmosferze awansowania jej na narodowe opus magnum. Nie mógł nie zastanawiać się nad tym, co powinien i pragnie powiedzieć czytelnikom tak hojnie przez Sienkiewicza pokrzepionym [...]. A powiedział im - pokrzepionym wspomnieniami dawnej świetności - że teraźniejszość jest polem walki bardziej dramatycznej niż przeszłość i że w tej walce nie zwyciężają ci, co - ze stanowiska dobra publicznego - zwyciężać powinni. I powiedział im - pokrzepionym pomyślnymi przesłaniami powieści Sienkiewicza - że nasza najbliższa przyszłość zasnuwa się niepokojącymi chmurami. I powiedział im - pokrzepionym wojennymi przygodami i pięknymi romansami pradziadów, że w zacofanym kraju dzisiejszym na pozycje opuszczone przez ludzi wartościowych instaluje się drapieżny geszeft, egoizm, cynizm, a i historie miłosne kończą się czasami fatalnie ${ }^{56}$.

[One should not cover the eyes to the fact that Prus was finishing his work in the spring of 1889, that was in the atmosphere of common applause for the fortifying advantages of The Trilogy and in the atmosphere of promoting it to the status of a national opus magnum. He could not think on what he should and desire to tell the readers risen in spirits by Sienkiewicz [...] And he told them - risen with memories of past splendour - that the present is a battlefield much more dramatic than the past

${ }^{54}$ Z. Szweykowski, op. cit., p. 104, cf. L. Ludorowski, Requiem finalne..., pp. 33-339.

${ }^{55} \mathrm{~L}, \mathrm{II}, 695$.

${ }^{56}$ J. Bachórz, Sienkiewicz - Orzeszkowa - Prus: spotkanie u szczytu twórczości, in: "Lalka" i inne. Studia w stulecie polskiej powieści realistycznej, J. Bachórz, M. Głowiński (eds.), IBL PAN, Warsaw 1992, p. 24. 
and that in this battle those who should win, from the point of view of the public good, do not win. And he told them - encouraged by the favourable messages of Sienkiewicz's novel - that our nearest future will be covered with disturbing clouds. And he told them - encouraged by their war adventures and beautiful love affairs of their great-grandfathers that in a backward country of today on the positions left by precious people one installs rapacious deal, egoism, cynicism and love stories end unfortunate.]

Those words are wise and very important for understanding the essence of the polemics between the writers, the encouraging message of Sienkiewicz and seasoned with pessimism of Prus's concern.

The repeating of "Ordon's gesture" is parodied by Sławomir Mrożek in the play entitled The Death of the Lieutenant, using literary transmutations of Adam Mickiewicz's poem. Echoes of the blowing up of the fortress (barricade) appear also in his story How did I fight. The same topic is raised by the writer in a cycle of drawings Poland on pictures published in Przekrój: Ordon, Wołodyjowski and Wokulski on consecutive illustrations blow themselves up in grotesque ways ${ }^{57}$. Mrożek parodies were an overt mockery of the romantic traditions and created (or transformed from medieval chansons de gestes) myths foraging on helplessness and collective hope for independence, which can be gained with martyrdom and sacrifice, myths inadequate to any reality, because interfering with common sense, disregarding life and glorifying death. However, Bolesław Prus did not treat the Sienkiewicz's ethos of Wołodyjowski in such an iconoclastic way, disputing with the author of The Trilogy as a conservatist, who created a protagonist unfit for the times of "social decay". Wołodyjowski, according to a compensating myth, strengthened the image of the absolute knight who remains faithful to the oath in spite of being abandoned by his command and doomed to defeat. The greatness of Wokulski is limited to the world of myth, a moving tale about a spiritual victory and exists as an ideal for young readers, as a paradigm of sacrificing privacy in the name of public affairs. For sensible Prus, Wołodyjowski, that "Hector of Kamianets-Podilskyi defending Polish Troy" was far from the original. He bore real emotions and brought tears but he strengthened the utopian or at the most the proportional vision of the past and shaped a impractical, based on fiction and visions, myth of an invincible knight, to whom - because of the shortcomings of body and mind exposed by Sienkiewicz - each young man could relate. Even more so, because the writer's talent was unrivalled, seductive, which in Prus the final parts of the review of With Fire and Sword emphasized poignantly:

${ }^{57}$ S. Mrożek, Polska w obrazach i inne polskie cykle, S. Rosiek (ed.), Słowo/Obraz Terytoria, Gdańsk 1998, pp. 235-237. 
Dzięki tym prześlicznym zdolnościom zarzuca on na duszę czytelnika tyle haczyków, że wywikłać się z nich nie można. Widzisz, słyszysz, dotykasz, czujesz, a w końcu wierzysz. A jest tych wrażeń takie mnóstwo, że wydaje ci się, że on nie pisze, ale że gra pełnymi akordami, całą orkiestrą, albo że maluje wszystkimi barwami tęczy. Jego styl jest szeroki i wzniosły; zaspakaja umysł, gdyż wyczerpuje przedmiot opisywany, a nadto pieści serce, gdyż Sienkiewicz ma smak arystokratyczny. W najwstrętniejszym przedmiocie znajdzie on jakieś cechy ładne, te wysuwa na pierwszy plan, a brzydkie zaciera. Gdy nie może tak zrobić z przedmiotem, wówczas oświetla go piękną sytuacją, a gdy mu i tego zabraknie - ozdabia melodią wyrazów. Tak wrażliwy smak jest bodaj czy nie najgłębszą cechą jego usposobienia; kto wie, czy nie on stworzył „historiozofią” powieści Ogniem i mieczem. Autor tak nie lubi podawać czytelnikowi rzeczy gorzkich, że nawet zmienił dzieje, pełne tylko goryczy... ${ }^{58}$

[Thanks to these lovely abilities he throws on the reader's neck so many snags that one cannot disentangle oneself. You see, you hear, you touch, you feel and finally you believe. There are so many such sensations that it seems to you that he doesn't write but plays with whole accords, whole orchestra or that he paints using all the colours of the rainbow. His style is broad and elevated; it satisfies the mind because of exhausting the object that is being described and what is more, caresses the heart because Sienkiewicz has aristocratic taste. In the most awful object he can find pretty characteristics, which he moves to the fore, whereas the ugly ones he tears off. When he cannot do it, then he lights it with a beautiful situation, whereas he is short if it - he decorates it with melody of the words. Such a sensible taste is probably the most profound characteristic of his disposition; who knows if he created The Fire and Sword with the "philosophy of history". The author does not like to give the reader bitter things, that even he changed the history, full of bitterness... $]^{59}$

Sienkiewicz's writing stemmed from opportunism. The writer was aware of the readers' expectations and watching the interest in The Trilogy (which was easier thanks to printing it in episodes), he could shape the plot in such a way that enabled him to satisfy them. Therefore, Prus introduced in Wołodyjowski's place a realistic character, typical for "transitional times", combining contradictions coming from changes: an amalgam of idealism and pragmatism. Thus, the protagonist of the epos met with the protagonist of the tragedy ${ }^{60}$, the essence of "native heroicum" 61 with the novel of "great questions of the epoch". Time, which did not need "to contemplate past battlefields of glory", because

58 B. Prus, Ogniem i mieczem..., p. 67.

59 Transl. by A. Banasiak.

${ }^{60}$ Amplification of this thesis See D. Samborska-Kukuć, "Lalka” Bolesława Prusa-pamięć tragedii greckiej - z problemów intertekstualności, Primum Verbum, Łódź 2011.

${ }^{61}$ J. Bachórz, "Lalka” w kontekście "Trylogii”..., p. 37. 
neither the present nor the past promised any "miracles of military triumphs", but required rational "economical calculations" ${ }^{62}$, which could bring economic success.

Interestingly, a continuation of similar patriotic polemics with the superhero blowing himself up will be the famous scene from Labours of Sisyphus, where Zygier's recitation of Ordon's redoubt showing mythical sacrifice of the title character, causes the ideological change of Marcin Borowicz, a student of the Russified gimnasium, who will gain the belief in the sense of Polishness and the necessity of fighting for Polish honour in a situation of humiliation and oppression. Is it the content of Redoubt that stimulated clerical student lost in reality or rather circumstances, in which a patriotic declamation took place? The personality of Bernard Zygier, the special situation of breaking a ban, the related threat and in consequence of collective rebellion, moodiness, loftiness and emotion, and then words of the poem - that is the decrescendo of the experiences with awakening patriotically middle school teens. He perceived it in this way in his draft about Sienkiewicz and was parodied in Ferdydurke by Witold Gombrowicz, conqueror of Sienkiewicz's myths "of easy charm".

\section{Bibliography}

Bachórz Józef, "Lalka" w kontekście "Trylogii", "Rocznik Towarzystwa Literackiego imienia Adama Mickiewicza", Year 26/27: 1991/1992, pp. 27-40.

Bachórz Józef, Sienkiewicz - Orzeszkowa - Prus: spotkanie u szczytu twórczości, w: "Lalka" i inne. Studia w stulecie polskiej powieści realistycznej, Józef Bachórz, Michał Głowiński (eds.), IBL PAN, Warsaw 1992, pp. 9-28.

Bartoszyński Kazimierz, Powieść w świecie literackości, IBL PAN, Warsaw 1991.

Bujnicki Tadeusz, Sześć szkiców o Zagłobie i inne studia sienkiewiczowskie, DiG, Warsaw 2014.

Chmielowski Piotr, “Lalka” Bolesława Prusa, „Ateneum” 1890, vol. 1, issue 3, pp. 471-483.

Eco Umberto, Lector i fabula. Współdziałanie w interpretacji tekstów narracyjnych, transl. Piotr Salwa, PIW, Warsaw 1994.

Krzemińska Wanda, Bohater mityczny w powieściach polskich i francuskich, PWN, Warsaw 1985. Krzyżanowski Julian, Kalendarz życia i twórczości Henryka Sienkiewicza, in: Henryk Sienkiewicz, Dzieła, vol. LVII, PIW, Warsaw 1954.

Krzyżanowski Julian, Pokłosie Sienkiewiczowskie, PIW, Warsaw 1973.

Kubaszewski Cezary, "Przecież to jasne, że Stach zabil się w Zastawiu...”. Dynamika znaczeń w odbiorze "Lalki" Bolestawa Prusa (w aspekcie zakończenia powieści), in: Nowe stulecie trójcy powieściopisarzy, Andrzej Makowiecki (ed.), Wydawnictwo UW 1992, pp. 183-195.

Ludorowski Lech, Wizjoner przeszłości. Powieści historyczne Henryka Sienkiewicza, Wydawnictwo UMCS, Lublin 1999.

Ludorowski Lech, Requiem finalne "Pana Wołodyjowskiego", in: idem, Wizjoner przeszłości. Powieści historyczne Henryka Sienkiewicza, Wydawnictwo UMCS, Lublin 1999, pp. 334-342.

${ }^{62}$ T. Bujnicki, op. cit., p. 77. 
Martuszewska Anna, Bolesława Prusa "prawidta" sztuki literackiej, Wydawnictwo UG, Gdańsk 2003. Martuszewska Anna, Światy (nie)możliwe powieści, Wydawnictwo UG, Gdańsk 2001.

Martuszewska Anna, Poetyka polskiej powieści dojrzałego realizmu 1876-1895, Ossolineum, Wroclaw 1977.

Matusiak Gabriela, Państwo Wołodyjowscy jako matżeństwo nie tylko barokowe, „Acta Universitatis Lodziensis. Folia Litteraria Polonica" vol. 7 (2005), issue 1, pp. 279-302.

Mazan Bogdan, Impresjonizm “Trylogii” Henryka Sienkiewicza, Wydawnictwo UŁ, Łódź 1993.

Mazan Bogdan, Wstęp, in: H. Sienkiewicz, Pan Wołodyjowski, Bogdan Mazan, Danuta Mazanowa (eds.), Ossolineum, Wroclaw 1995, pp. 3-90.

Meresiński Sławomir, Henryk Sienkiewicz wobec tradycji romantycznej, Wydawnictwo Pedagogiczne, Kielce 1992.

Mrożek Sławomir, Polska w obrazach i inne polskie cykle, Stanisław Rosiek (ed.), Słowo/Obraz Terytoria, Gdańsk 1998.

Piwińska Marta, Legenda romantyczna i szydercy, IBL PAN, Warsaw 1973.

Prus Bolesław, "Ogniem i mieczem". Powieść z dawnych lat Henryka Sienkiewicza, in: idem, Pisma, vol. XXIX, Studia literackie, artystyczne i polemiki, Zygmunt Szweykowski (ed.), PIW, Warsaw 1950.

Prus Bolesław, Lalka, vol. 1-2, Józef Bachórz (ed.), Ossolineum, Wroclaw 1998.

Samborska-Kukuć Dorota, "Lalka" Bolesława Prusa - pamięć tragedii greckiej. Z problemów intertekstualności, Primum Verbum, Łódź 2011.

Sienkiewicz Henryk, Dzieła zebrane, vol. 7-19, Julian Krzyżanowski (ed.), PIW, Warsaw 1949.

Szweykowski Zygmunt, "Trylogia” Sienkiewicza i inne szkice o twórczości pisarza, Wydawnictwo Poznańskie, Poznań 1973.

Tomkowski Jan, Prawdziwe zakończenie "Lalki", albo co się stało z Wokulskim, in: Bolesław Prus: pisarz nowoczesny, Jakub A. Malik (ed.), Wydawnictwo KUL, Lublin 2009, pp. 9-21.

Dorota Samborska-Kukuć

\section{What a Suave Man he Was! [...] The Earth Trembled as he Perished Two Polish Suicides: Wołodyjowski - Wokulski}

\section{(Summary)}

There is more to the literary polemic between the author of The Doll and the creator of The Trilogy than merely Prus' contradictory review of Sienkiewicz's With Fire and Sword. It also includes The Doll's multifarious allusiveness to Fire in the Steppe, manifested in particular in the meaningful, symbolic ending, whereby both protagonists blow themselves up, literally and metaphorically cornered in old buildings. Prus converses with Sienkiewicz in a discreet manner, though the careful reader will spot contentious issues. These include the struggle for a different type of protagonist - not a hero, but an individual entangled in romantic myths, paralysing their life forces; a different perception of the past, rational and fair rather than glorified and martyrological; finally, a different outlook on the present and the future, promoting entrepreneurship and economy as tools for the development of Poland as a European partner, rather than the idealistic focus on the utopian, foregone concepts of military achievements. 
The text highlights the similarities in the characters of Wokulski and Wołodyjowski, with special emphasis on the final scenes and the demise of the world after the protagonists' respective disappearance. The two famous literary suicides, patterning after the deed of Ordon as depicted in Mickiewicz's poem, have been parodied (e.g. by Mrożek) and adopted, thus becoming literary weapons in the struggle with the Polish mythopoeia, xenophobia, and exaggerated patriotism.

Keywords: The Doll of Bolesław Prus; Colonel Wołodyjowski of Henryk Sienkiewicz; polish myths; suicide 